\title{
Reduction of GTP Cyclohydrolase I Feedback Regulating Protein Expression by Hydrogen Peroxide in Vascular Endothelial Cells
}

\author{
Masakazu Ishii ${ }^{1} *$, Shunichi Shimizu ${ }^{1}$, Teruaki Wajima ${ }^{1}$, Tamio Hagiwara ${ }^{2}$, Takaharu Negoro ${ }^{3}$, \\ Akira Miyazaki ${ }^{2}$, Takashi Tobe ${ }^{3}$, and Yuji Kiuchi ${ }^{1}$ \\ Departments of ${ }^{1}$ Pathophysiology and ${ }^{3}$ Medicinal Information, School of Pharmaceutical Sciences, Showa University, \\ Shinagawa-ku, Tokyo 142-8555, Japan \\ ${ }^{2}$ Department of Biochemistry, School of Medicine, Showa University, Shinagawa-ku, Tokyo 142-8555, Japan
}

Received October 12, 2004; Accepted December 22, 2004

\begin{abstract}
We examined the effect of $\mathrm{H}_{2} \mathrm{O}_{2}$ on the expression of GTP cyclohydrolase I (GTPCH) feedback regulating protein (GFRP). Addition of $\mathrm{H}_{2} \mathrm{O}_{2}$ to endothelial cells decreased GFRP mRNA levels, in contrast to the increase of tetrahydrobiopterin $\left(\mathrm{BH}_{4}\right)$ content and GTPCH mRNA levels. The inhibitors of nitric oxide (NO) synthase and GTPCH had no influence on the decrease of GFRP mRNA levels in $\mathrm{H}_{2} \mathrm{O}_{2}$-treated cells. It is suggested that $\mathrm{H}_{2} \mathrm{O}_{2}$ induces $\mathrm{BH}_{4}$ synthesis through not only induction of GTPCH but also reduction of GFRP. The decrease of GFRP mRNA level appears to be independent of the produced $\mathrm{NO}$ and $\mathrm{BH}_{4}$.
\end{abstract}

Keywords: GTP cyclohydrolase I, GTP cyclohydrolase I feedback regulating protein, hydrogen peroxide

Tetrahydrobiopterin $\left(\mathrm{BH}_{4}\right)$ is an essential cofactor for nitric oxide (NO) synthase (NOS) $(1,2)$, and also has a protective effect against toxicities of reactive oxygen species (ROS) $(1,2)$. It is generally accepted that $\mathrm{BH}_{4}$ is an important molecular target for oxidative stress leading to vascular injury in various diseases, including hypercholesterolemia, diabetes mellitus, and hypertension, since $\mathrm{BH}_{4}$ is easily oxidized by $\operatorname{ROS}(1,2)$. The biosynthesis of $\mathrm{BH}_{4}$ can occur via a de novo pathway from guanosine triphosphate (GTP), in which the enzyme GTP cyclohydrolase I (GTPCH) catalyzes the rate-limiting step $(1,2)$. Although the regulation mechanisms underlying the activation and expression of GTPCH in vascular endothelial cells are yet to be elucidated, the enzyme activity has been shown to be reduced by $\mathrm{BH}_{4}$ through the formation of a ternary complex among $\mathrm{BH}_{4}, \mathrm{GTPCH}$, and GTPCH feedback regulatory protein (GFRP) by using the purified enzymes (3).

Interestingly, we recently reported that $\mathrm{H}_{2} \mathrm{O}_{2}$, one of the ROS, stimulates $\mathrm{BH}_{4}$ synthesis through the induction of GTPCH in vascular endothelial cells (4). However, the mechanism of $\mathrm{H}_{2} \mathrm{O}_{2}$-induced $\mathrm{BH}_{4}$ synthesis is not

*Corresponding author. FAX: +81-3-3786-0481

E-mail: masakazu@pharm.showa-u.ac.jp clear. To understand the underlying mechanisms of vascular injury by oxidative stress, it is important to determine the stimulation mechanisms of $\mathrm{BH}_{4}$ synthesis by $\mathrm{H}_{2} \mathrm{O}_{2}$. Proinflammatory cytokines and lipopolysaccharide (LPS), which are known to stimulate $\mathrm{BH}_{4}$ synthesis with GTPCH induction, decrease the expression of GFRP $(5,6)$.

In the present study, the effect of $\mathrm{H}_{2} \mathrm{O}_{2}$ on the expression of GFRP mRNA was examined, and the changes were compared with that of GTPCH mRNA, in vascular endothelial cells. We found that $\mathrm{H}_{2} \mathrm{O}_{2}$ decreases GFRP mRNA levels, in contrast to the increases of GTPCH mRNA levels. The reduction of GFRP expression is likely to be implicated in the increases of $\mathrm{BH}_{4}$ content by $\mathrm{H}_{2} \mathrm{O}_{2}$.

Mouse brain microvascular endothelial cells (MBMECs, 2nd passage) were purchased from Toyobo Co. (Osaka). The cells were cultured in Dulbecco's modified Eagle's medium (DMEM) containing 10\% fetal bovine serum, $100 \mathrm{U} / \mathrm{ml}$ penicillin, and $100 \mu \mathrm{g} / \mathrm{ml}$ streptomycin. Cells were used at 5 to 20 passages after purchase. Confluent MBMECs in 6-well plates or 100$\mathrm{mm}$ culture dishes were washed twice with physiological saline solution (PSS, $\mathrm{pH} 7.4$ ) containing $118.5 \mathrm{mM} \mathrm{NaCl}, 4.74 \mathrm{mM} \mathrm{KCl}, 2.5 \mathrm{mM} \mathrm{CaCl}_{2}$, 
$1.18 \mathrm{mM} \mathrm{MgSO}_{4}, 1.18 \mathrm{mM} \mathrm{KH}_{2} \mathrm{PO}_{4}, 2.5 \mathrm{mM} \mathrm{NaHCO}$, $11 \mathrm{mM}$ glucose, and $10 \mathrm{mM} \mathrm{N}$-2-hydroxyethylpiperazine- $N^{\prime}$-2-ethanesulfonic acid; and then they were treated with $\mathrm{H}_{2} \mathrm{O}_{2}$ at $37^{\circ} \mathrm{C}$ in $2 \mathrm{ml}$ (6-well plates) or $10 \mathrm{ml}$ (100-mm dishes) of PSS.

The total biopterin $\left(\mathrm{BH}_{4}\right.$ plus 7,8-dihydrobiopterin $\left(\mathrm{BH}_{2}\right)$ plus biopterin) content in MBMECs was measured by oxidizing in $0.02 \mathrm{M} \mathrm{KI} / \mathrm{I}_{2}$ in $0.1 \mathrm{M} \mathrm{HCl}$, as previously described (4).

The preparation of cDNA probes for GTPCH and glyceraldehydes-3-phoshate-dehydrogenase (GAPDH) and Northern blot analysis for GTPCH and GAPDH mRNAs were performed as previously described (7). GFRP cDNA probe was prepared by RT-PCR, using pairs of primers, 5'-GGAGTCCTTGGACCGGAGAAG AAC-3' and 5'-CCGAGAGTTTGGAACTTTCCACG3', and GFRP mRNA levels were measured by Northern blot analysis.

Addition of $\mathrm{H}_{2} \mathrm{O}_{2}(100 \mu \mathrm{M})$ to MBMECs increased the total biopterin content from $9 \mathrm{~h}$ after its treatment (Fig. 1). We recently reported that the treatment with $\mathrm{H}_{2} \mathrm{O}_{2}$ increases $\mathrm{BH}_{4}$ without significant increasing of its oxidized forms (4). To determine whether $\mathrm{H}_{2} \mathrm{O}_{2}$ affects the expression of GTPCH and GFRP mRNA levels, Northern blot analysis was employed. The endothelial cells expressed low levels of GTPCH mRNA and high levels of GFRP mRNA in the basal conditions. Hydrogen peroxide $(100 \mu \mathrm{M})$ induced the expression of the GTPCH mRNA levels from $3 \mathrm{~h}$ after its treatment (Fig. 2A). In contrast to GTPCH mRNA, Northern blot analysis revealed that the basal GFRP mRNA levels were decreased by the treatment with $\mathrm{H}_{2} \mathrm{O}_{2}$ (Fig. 2: A and $\mathrm{B})$. We previously showed that $\mathrm{BH}_{4}$ synthesis and GTPCH mRNA levels were concentration-dependently

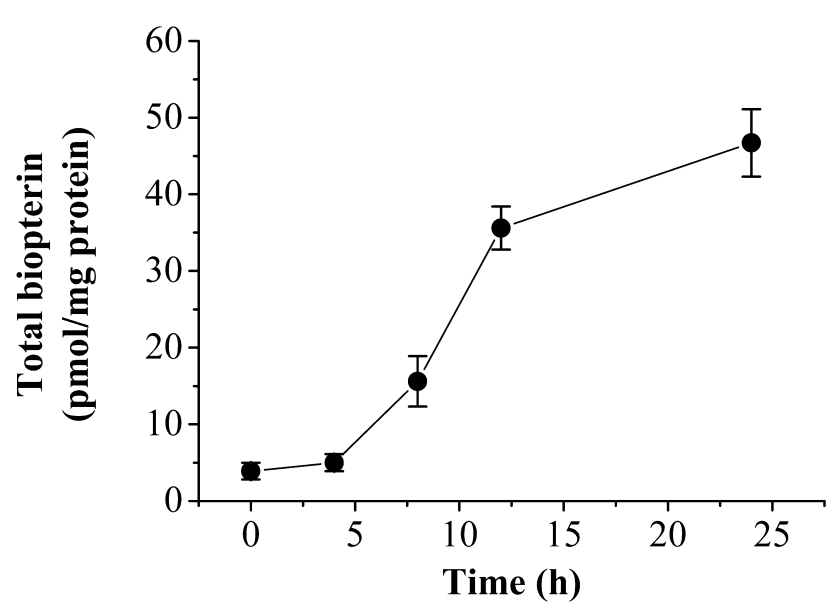

Fig. 1. Effects of $\mathrm{H}_{2} \mathrm{O}_{2}$ on total biopterin content in MBMECs. Cells were incubated with $\mathrm{H}_{2} \mathrm{O}_{2}(100 \mu \mathrm{M})$ for various periods $(0-$ $24 \mathrm{~h})$ at $37^{\circ} \mathrm{C}$. Values are the means \pm S.E.M. of 3 experiments. increased by $\mathrm{H}_{2} \mathrm{O}_{2}$, and both the increases were reduced by the co-treatment with catalase $(4,8)$. As shown in Fig. $2 \mathrm{C}$, the reduction of GFRP mRNA levels by $\mathrm{H}_{2} \mathrm{O}_{2}$ was also inhibited by the co-treatment with catalase (100 U/ml).

To determine whether the $\mathrm{NO}$ and $\mathrm{BH}_{4}$ produced by $\mathrm{H}_{2} \mathrm{O}_{2}$ treatment were involved in the reduction of GFRP mRNA expression, the effects of $\mathrm{L}-N^{6}$-(1-iminoethyl) lysine (L-NIL), an iNOS inhibitor, and 2,4-diamino-6hydroxypyrimidine (DAHP), a GTPCH inhibitor, were examined. Both L-NIL and DAHP did not affect the decrease of GFRP mRNA expression by $\mathrm{H}_{2} \mathrm{O}_{2}$ (Fig. 3: A

A

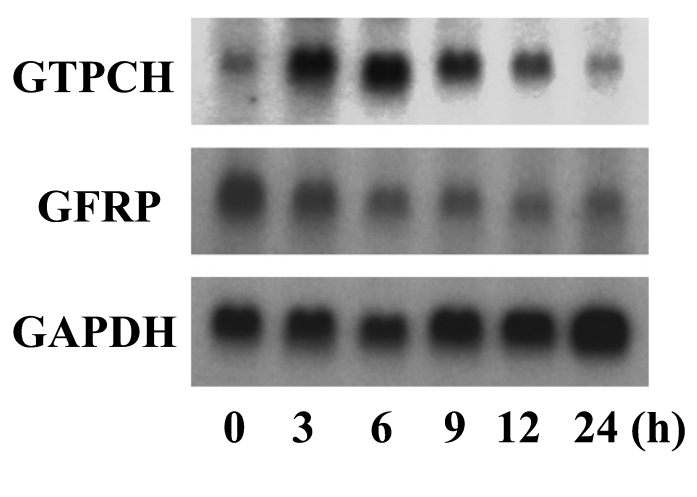

B
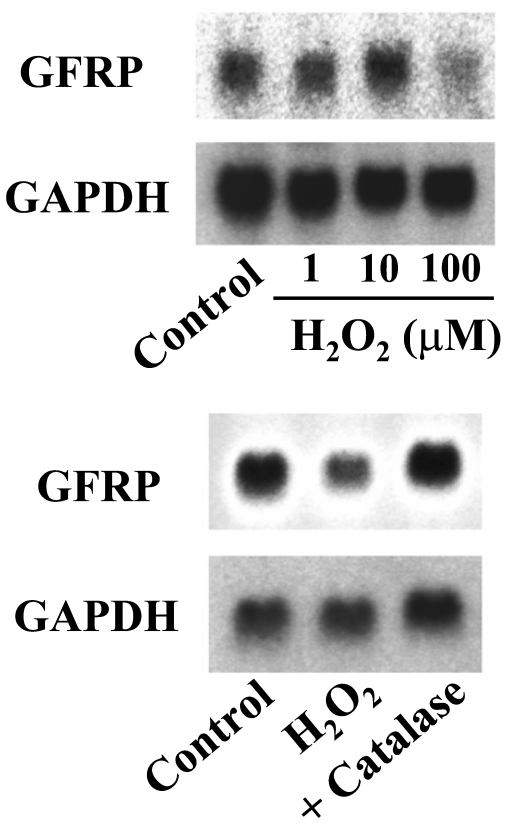

Fig. 2. Changes in GTPCH and GFRP mRNA levels by $\mathrm{H}_{2} \mathrm{O}_{2}$ treatment. A: Cells were incubated with $\mathrm{H}_{2} \mathrm{O}_{2}(100 \mu \mathrm{M})$ for various periods $(0-24 \mathrm{~h})$. B: Cells were incubated with $\mathrm{H}_{2} \mathrm{O}_{2}(1-100 \mu \mathrm{M})$ for $12 \mathrm{~h}$. C: Cells were pretreated with catalase $(100 \mathrm{U} / \mathrm{ml})$ for $1 \mathrm{~h}$ and then treated with $\mathrm{H}_{2} \mathrm{O}_{2}(100 \mu \mathrm{M})$ for $12 \mathrm{~h}$. After incubation, the total RNA was extracted, and then the expression of GTPCH, GFRP, and GAPDH mRNA levels were determined by Northern blot analysis. 
and B). Moreover, $S$-nitroso- $N$-acetyl-D,L-penicillamine (SNAP, $0.01-1 \mathrm{mM}$ ), a NO donor, did not reduce GFRP mRNA levels (Fig. 3C).

In the present study, we observed the expression of GFRP mRNA in basal conditions, and the expression was decreased by the treatment with $\mathrm{H}_{2} \mathrm{O}_{2}$, in contrast to the increase of GTPCH mRNA levels and $\mathrm{BH}_{4}$ content. Previous reports showed the involvement of GFRP in $\mathrm{BH}_{4}$ synthesis by treatment with LPS and/or cytokines in various types of cells. Werner et al. (5) reported that LPS, which is known to stimulate $\mathrm{BH}_{4}$ synthesis through a de novo pathway with the induction of GTPCH, downregulates the expression of GFRP mRNA level in human

A

\section{GFRP}

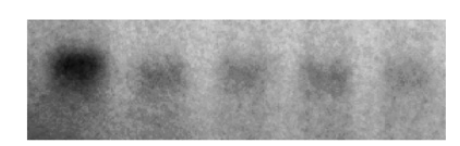

\section{GAPDH}
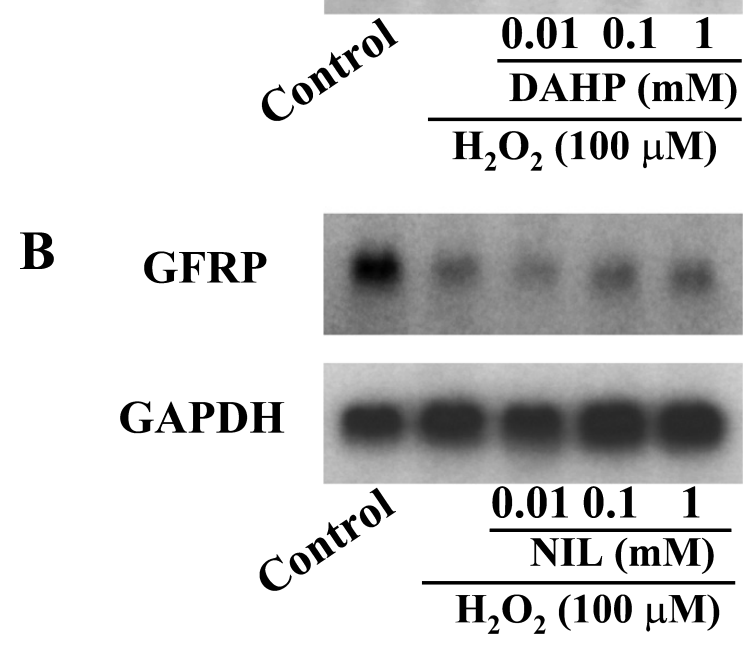

C

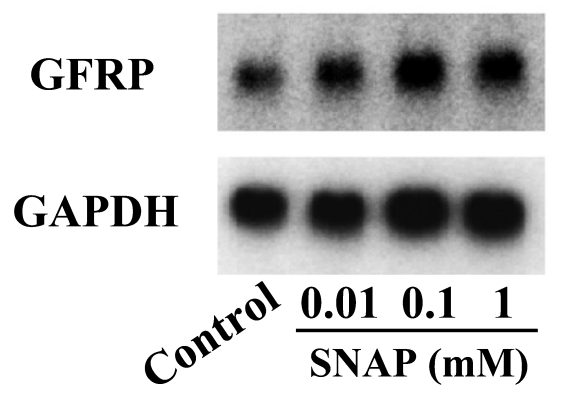

Fig. 3. Effects of GTPCH and iNOS inhibitors on the expression of GFRP mRNA expression during $\mathrm{H}_{2} \mathrm{O}_{2}$ treatment in MBMECs. Cells were pretreated with DAHP $(0.01-1 \mathrm{mM}$, A) or L-NIL $(0.01-1 \mathrm{mM}, \mathrm{B})$ for $15 \mathrm{~min}$ and then incubated with $\mathrm{H}_{2} \mathrm{O}_{2}(100 \mu \mathrm{M})$ for $12 \mathrm{~h}$. C: Cells were incubated with $\operatorname{SNAP}(0.01-1 \mathrm{mM})$ for $12 \mathrm{~h}$. After incubation, the total RNA was extracted, and then the expression of GFRP and GAPDH mRNA levels were determined by Northern blot analysis.
THP-1 myelomonocytoma. Gesierich et al. (6) also showed that interferon- $\gamma$ up-regulates the expression of GTPCH mRNA and down-regulates GFRP mRNA in human umbilical vein endothelial cells. Thus, the decrease of GFRP seems to be implicated in the stimulation of $\mathrm{BH}_{4}$ synthesis by not only LPS and/or cytokines but also $\mathrm{H}_{2} \mathrm{O}_{2}$.

Park et al. (9) recently suggested that NO decreases GFRP mRNA levels. However, an iNOS inhibitor, LNIL, which completely blocked NO production in $\mathrm{H}_{2} \mathrm{O}_{2}$ treated cells (4), had no effect on the reduction of GFRP mRNA expression. The NO donor SNAP also did not reduce the expression of GFRP mRNA levels in our experimental conditions. The discrepancy may reflect the effect of NO on GFRP mRNA expression in different cell types and species. Moreover, although we previously showed that the GTPCH inhibitor DAHP ( $1 \mathrm{mM}$ ) completely inhibited $\mathrm{H}_{2} \mathrm{O}_{2}$-induced $\mathrm{BH}_{4}$ synthesis (4), it had no effect on the reduction of GFRP expression. These observations suggest that endogenously produced $\mathrm{NO}$ and $\mathrm{BH}_{4}$ are not implicated in the underlying mechanisms of GFRP mRNA reduction by $\mathrm{H}_{2} \mathrm{O}_{2}$. Recently, $\mathrm{H}_{2} \mathrm{O}_{2}$ has been shown to stimulate various signaling cascades including extracellular signal-regulated protein kinase (ERK), leading to cell survival and proliferation $(10,11)$. In the future, we will need to clarify the mechanism by which $\mathrm{H}_{2} \mathrm{O}_{2}$ decreases GFRP mRNA.

In conclusion, our findings suggest that $\mathrm{H}_{2} \mathrm{O}_{2}$ induces $\mathrm{BH}_{4}$ synthesis through not only the induction of GTPCH but also the decrease of GFRP. The decrease of GFRP mRNA level appears to be independent of the produced $\mathrm{NO}$ and $\mathrm{BH}_{4}$. The stimulation of $\mathrm{BH}_{4}$ synthesis by decreasing GFRP might be one of the defense systems against oxidative stress since $\mathrm{BH}_{4}$ has an antioxidative activity.

\section{References}

1 Shimizu S, Ishii M, Momose K, Yamamoto T. Role of tetrahydrobiopterin in the function of nitric oxide synthase, and its cytoprotective effect (Review). Int J Mol Med. 1998;2:533-540.

2 Ishii M, Shimizu S, Yamamoto T, Kiuchi Y. Possible role of $\mathrm{BH} 4$ as one of the cell defense system against reactive oxygen species-induced toxicity. Recent Res Dev Life Sci. 2003;1:195202.

3 Yoneyama T, Hatakeyama K. Decameric GTP cyclohydrolase I forms complexes with two pentameric GTP cyclohydrolase I feedback regulatory proteins in the presence of phenylalanine or of a combination of tetrahydrobiopterin and GTP. J Biol Chem. 1998;273:20102-20108.

4 Shimizu S, Shiota K, Yamamoto S, Miyasaka Y, Ishii M, Watabe $\mathrm{T}$, et al. Hydrogen peroxide stimulates tetrahydrobiopterin synthesis through the induction of GTP-cyclohydrolase I and increases nitric oxide synthase activity in vascular endo- 
thelial cells. Free Radic Biol Med. 2003;34:1343-1352.

5 Werner ER, Bahrami S, Heller R, Werner-Felmayer G. Bacterial lipopolysaccharide down-regulates expression of GTP cyclohydrolase I feedback regulatory protein. J Biol Chem. 2002;277:10129-10133.

6 Gesierich A, Niroomand F, Tiefenbacher CP. Role of human GTP cyclohydrolase I and its regulatory protein in tetrahydrobiopterin metabolism. Basic Res Cardiol. 2003;98:69-75.

7 Ishii M, Shimizu S, Shiota K, Yamamoto S, Kiuchi Y, Yamamoto T. Stimulation of tetrahydrobiopterin synthesis by cyclosporin A in mouse brain microvascular endothelial cells. Int J Biochem Cell Biol. 2002;34:1134-1141.

8 Shimizu S, Ishii M, Miyasaka Y, Wajima T, Negoro T, Hagiwara $\mathrm{T}$, et al. Possible involvement of hydroxyl radical on the stimulation of tetrahydrobiopterin synthesis by $\mathrm{H}_{2} \mathrm{O}_{2}$ and peroxynitrite in vascular endothelial cells. Int J Biochem Cell Biol. In press 9 Park JH, Na HJ, Kwon YG, Ha KS, Lee SJ, Kim CK, et al. Nitric oxide (NO) pretreatment increases cytokine-induced NO production in cultured rat hepatocytes by suppressing GTP cyclohydrolase I feedback inhibitory protein level and promoting inducible NO synthase dimerization. J Biol Chem. 2002;277: 47073-47079.

10 Guyton KZ, Liu Y, Gorospe M, Xu Q, Holbrook NJ. Activation of mitogen-activated protein kinase by $\mathrm{H}_{2} \mathrm{O}_{2}$. Role in cell survival following oxidant injury. J Biol Chem. 1996;271:41384142.

11 Arany I, Megyesi JK, Kaneto H, Tanaka S, Safirstein RL. Activation of ERK or inhibition of JNK ameliorates $\mathrm{H}_{2} \mathrm{O}_{2}$ cytotoxicity in mouse renal proximal tubule cells. Kidney Int. 2004;65:1231-1239. 